Conclusion: PsA and Ps have proved to be diseases with a high economic burden, and the total costs were mainly driven by direct non-healthcare costs. Moreover, although annual total costs in patients with PsA were similar to those of Ps patients, the combination of both manifestations yielded the highest costs suggesting the importance of the increased disease load.

Disclosure of Interests: Santos Castañeda: None declared, Esther Vicente Speakers bureau: BMS, Roche., Mar Llamas Velasco: None declared, Javier Sanchez Perez: None declared, José Pardo: None declared, Rita CabezaMartínez: None declared, Mercedes Miranda-Fontes: None declared, Juan Márquez: None declared, Jaime Calvo Grant/research support from: Lilly, UCB, Consultant of: Abbvie, Jansen, Celgene, susana armesto: None declared, Isabel Belinchón: None declared, Alejandro Gómez: None declared, María Dolores Miranda: None declared, Silvia Martinez Pardo: None declared, Leticia Merino-Meléndez: None declared, Miguel Angel Casado Consultant of: UCB Pharma, María Yébenes: None declared, Araceli Casado: None declared DOI: 10.1136/annrheumdis-2020-eular.3298

\section{OP0263-HPR MAJOR STRESSORS IN THE YEAR PRIOR TO RA DIAGNOSIS: IMPACT ON PATIENT-REPORTED OUTCOMES ONE YEAR LATER}

N. Andersen ${ }^{1}$, O. Schieir ${ }^{2}$, M. F. Valois ${ }^{1}$, G. Boire ${ }^{3}$, J. Pope ${ }^{4}$, G. Hazlewood ${ }^{5}$, L. Bessette ${ }^{6}$, C. Hitchon ${ }^{7}$, D. Tin ${ }^{8}$, C. Thorne ${ }^{8}$, E. Keystone ${ }^{2}$, V. Bykerk' ${ }^{9}$, S. J. Bartlett ${ }^{1}$ on behalf of CATCH Investigators. ${ }^{1}$ Mc Gill University, Montreal, Canada; ${ }^{2}$ University of Toronto, Toronto, Canada; ${ }^{3}$ University of Sherbrooke, Sherbrooke, Canada; ${ }^{4}$ Western University, London, Canada; ${ }^{5}$ University of Calgary, Calgary, Canada; ${ }^{6}$ University of Laval, Quebec City, Canada; ${ }^{7}$ University of Manitoba, Winnipeg, Canada; ${ }^{8}$ Southlake Regional Health Centre, Newmarket, Canada; ${ }^{9}$ Hospital for Special Surgery, New York, United States of America

Background: Stress is implicated in RA onset and poorer prognoses through changes in neuro-endocrine and autoimmune function. Although many people with RA link disease onset to recent stressful life events, results from retrospective studies are unclear.

Objectives: To describe the incidence of major stressors (+STRESS) in year prior to diagnosis and compare characteristics and patient-reported outcomes (PROs) of newly diagnosed RA patients with and without +STRESS at 0 and 12 months.

Methods: Data were from early RA patients (symptoms $<1 \mathrm{yr}$ ) enrolled in the Canadian Early Arthritis Cohort (CATCH) from 2007-17 who met 1987/2010 ACR/ EULAR criteria and had $\geq 12$ months of follow-up. Patients reported major psychological (death, divorce/separation, family, financial, other) and physical (motor vehicle accident, surgery, major illness/infection, other) stressors in previous year. We used independent $t$-tests and chi square to compare characteristics by stressors at baseline, and multivariable regression to examine the impact of +STRESS on disease activity and PROs at 1 year, adjusting for age, sex, education, fibromyalgia, and SJC.

Results: The 1933 adults were mostly female (72\%), with a mean (SD) age of 55 (15) years. $52 \%$ reported $1+$ stressors in previous year; family $(48 \%)$, financial stress $(36 \%)$, death $(35 \%)$, surgery $(28 \%)$, and major illness $(26 \%)$ were the most common stressors. Patients with +STRESS were more likely to be women, younger, have more comorbidities including fibromyalgia, and higher mean DAS28. Patients with +STRESS also had significantly higher mean pain, fatigue, depression, sleep disturbance, patient global, and HAQ scores at baseline.

At 1 year, SJC and the proportion in DAS28 REM was similar between groups. However, PROs (pain, HAQ, Fatigue, Pt Global, Depression, Poor Sleep) remained higher in +STRESS, with evidence of an additive effect for number of stressors and having both physical and psychological stressors (Table). The greatest impacts were on mood, sleep disturbance, and fatigue.

Conclusion: In this pan-Canadian early RA cohort, more than half reported 1+ stressful life events in the year prior to diagnosis. Individuals reporting major stressors had significantly worse pain, patient global, disability, depression, fatigue, and sleep disturbance at diagnosis; 1 year later, though disease activity was similar between groups, the effects of +STRESS on PROs persisted. Early RA patients with recent major stressors may benefit from emotional support and stress reduction to optimize how they feel and function.

\begin{tabular}{lcccc}
\hline Mean (SD) or N (\%) & $\begin{array}{c}\text { No Stress } \\
(\mathrm{N}=928 ; 48 \%)\end{array}$ & $\begin{array}{c}\text { Physical } \\
(\mathrm{N}=131 ; 7 \%)\end{array}$ & $\begin{array}{c}\text { Psychological } \\
(\mathrm{N}=658 ; 34 \%)\end{array}$ & $\begin{array}{c}\text { Both } \\
(\mathrm{N}=216 ; 11 \%)\end{array}$ \\
\hline Age & $56(15)$ & $56(15)$ & $53(14)$ & $52(15)$ \\
Women & $622(67 \%)$ & $82(63 \%)$ & $512(78 \%)$ & $174(81 \%)$ \\
College Education & $464(50 \%)$ & $76(58 \%)$ & $345(52 \%)$ & $126(58 \%)$ \\
Rheum Dis Comorbid Index & $1.1(1.2)$ & $1.4(1.4)$ & $1.1(1.3)$ & $1.4(1.3)$ \\
OA or Spinal pain & $168(18 \%)$ & $35(27 \%)$ & $117(18 \%)$ & $55(25 \%)$ \\
Fibromyalgia diagnosis & $15(2 \%)$ & $2(2 \%)$ & $13(2 \%)$ & $11(5 \%)$ \\
Symptom duration (months) & $5.6(3.0)$ & $5.7(3.0)$ & $5.9(3.0)$ & $5.9(3.0)$
\end{tabular}

\begin{tabular}{lcccc}
\hline Mean (SD) or N (\%) & $\begin{array}{c}\text { No Stress } \\
(\mathrm{N}=928 ; 48 \%)\end{array}$ & $\begin{array}{c}\text { Physical } \\
(\mathrm{N}=131 ; 7 \%)\end{array}$ & $\begin{array}{c}\text { Psychological } \\
(\mathrm{N}=658 ; 34 \%)\end{array}$ & $\begin{array}{c}\text { Both } \\
(\mathrm{N}=216 ; 11 \%)\end{array}$ \\
\hline DAS28 - mean & $5.0(1.4)$ & $5.1(1.5)$ & $5.0(1.5)$ & $5.2(1.4)$ \\
MTX \pm csDMARDs & $679(73 \%)$ & $100(76 \%)$ & $489(74 \%)$ & $166(77 \%)$ \\
Oral Steroids & $295(32 \%)$ & $40(31 \%)$ & $215(33 \%)$ & $55(25 \%)$ \\
Pain (0-10) & $5.3(2.8)$ & $5.5(2.9)$ & $5.7(2.8)$ & $6.2(2.8)$ \\
HAQ-DI & $1.0(0.7)$ & $1.2(0.7)$ & $1.1(0.7)$ & $1.3(0.7)$ \\
Fatigue (0-10) & $4.7(3.1)$ & $5.0(3.0)$ & $5.7(2.9)$ & $5.9(2.9)$ \\
Patient Global (0-10) & $5.6(2.9)$ & $6.0(2.9)$ & $6.0(2.9)$ & $6.4(3.0)$ \\
Depression (SF12 MCS < 45.6) & $329(35 \%)$ & $54(41 \%)$ & $356(54 \%)$ & $123(57 \%)$ \\
Poor sleep (0-10) & $4.5(3.4)$ & $4.8(3.3)$ & $5.3(3.2)$ & $6.0(3.1)$ \\
\end{tabular}

Effect of stress in year prior to diagnosis on outcomes at 12 months $(\mathrm{N}=1933)$.

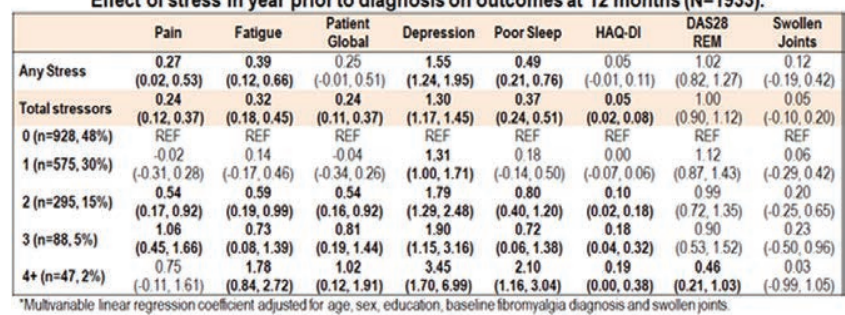

Disclosure of Interests: Nicole Andersen: None declared, Orit Schieir: None declared, Marie-France Valois: None declared, Gilles Boire Grant/research support from: Merck Canada (Registry of biologices, Improvement of comorbidity surveillance)

Amgen Canada (CATCH, clinical nurse)

Abbvie (CATCH, clinical nurse)

Pfizer (CATCH, Registry of biologics, Clinical nurse)

Hoffman-LaRoche (CATCH)

UCB Canada (CATCH, Clinical nurse)

BMS (CATCH, Clinical nurse, Observational Study Protocol IM101664. SERO-

POSITIVITY IN A LARGE CANADIAN OBSERVATIONAL COHORT)

Janssen (CATCH)

Celgene (Clinical nurse)

Eli Lilly (Registry of biologics, Clinical nurse), Consultant of: Eli Lilly, Janssen, Novartis, Pfizer, Speakers bureau: Merck, BMS, Pfizer, Janet Pope Grant/research support from: AbbVie, Bristol-Myers Squibb, Eli Lilly \& Company, Merck, Roche, Seattle Genetics, UCB, Consultant of: AbbVie, Actelion, Amgen, Bayer, Boehringer Ingelheim, Bristol-Myers Squibb, Eicos Sciences, Eli Lilly \& Company, Emerald, Gilead Sciences, Inc., Janssen, Merck, Novartis, Pfizer, Roche, Sandoz, Sanofi, UCB, Speakers bureau: UCB, Glen Hazlewood: None declared, Louis Bessette Grant/research support from: AbbVie, Amgen, Bristol-Myers Squibb, Celgene, Eli Lilly, Janssen, Merck, Novartis, Pfizer, Roche, Sanofi, UCB Pharma, Consultant of: AbbVie, Amgen, Bristol-Myers Squibb, Celgene, Eli Lilly, Janssen, Merck, Novartis, Pfizer, Roche, Sanofi, UCB Pharma, Speakers bureau: AbbVie, Amgen, Bristol-Myers Squibb, Celgene, El Lilly, Janssen, Merck, Novartis, Pfizer, Sanofi, Carol Hitchon Grant/research support from: UCB Canada; Pfizer Canada, Diane Tin: None declared, Carter Thorne Consultant of: Abbvie, Centocor, Janssen, Lilly, Medexus/Medac, Pfizer

Speakers bureau: Medexus/Medac, Edward Keystone Grant/research support from: AbbVie, Amgen, Bristol-Myers Squibb, F. Hoffmann-La Roche Inc, Gilead Janssen Inc, Lilly Pharmaceuticals, Pfizer Pharmaceuticals, Sanofi-Aventis, Consultant of: AbbVie, Amgen, AstraZeneca Pharma, Biotest, Bristol-Myers Squibb Company, Celltrion,

Crescendo Bioscience, F. Hoffmann-La Roche Inc, Genentech Inc, Gilead, Janssen Inc, Lilly

Pharmaceuticals, Merck, Pfizer Pharmaceuticals, Sandoz, UCB., Speakers bureau: Amgen, AbbVie, Bristol-Myers Squibb Canada, F. Hoffmann-La Roche Inc., Janssen Inc., Merck, Pfizer Pharmaceuticals, Sanofi Genzyme, UCB, Vivian Bykerk: None declared, Susan J. Bartlett Consultant of: Pfizer, UCB, Lilly, Novartis, Merck, Janssen, Abbvie, Speakers bureau: Pfizer, UCB, Lilly, Novartis, Merck, Janssen, Abbvie

DOI: 10.1136/annrheumdis-2020-eular.4826

\section{OP0264-HPR PERSPECTIVES ON APPROACHES TO PREDICT THE DEVELOPMENT OF RHEUMATOID ARTHRITIS: A QUANTITATIVE ASSESSMENT OF PATIENTS AND THEIR FIRST DEGREE RELATIVES}

I. Wells $^{1}$, G. Simons2, R. Stack2, C. Mallen ${ }^{3}$, P. Nightingale2, K. Raza2, M. Falahee2. ${ }^{1}$ University of Birmingham, Birmingham, United Kingdom; ${ }^{1}$ University of Birmingham, Birmingham, United Kingdom; ${ }^{3}$ Keele University, Keele, United Kingdom

Background: There is considerable interest within the medical research community in the identification of individuals at risk of developing rheumatoid arthritis 
(RA), to identify those who may benefit from preventive interventions. However, it is important to understand the views of those who may be candidates for such predictive tests, to inform the development of effective approaches. First degree relatives (FDRs) of patients with RA are at an increased risk of developing RA. RA patients can provide access to FDRs. Qualitative investigations have explored the views of these groups about predictive testing for $R A^{1,2}$, but quantitative approaches are needed to develop a robust understanding.

Objectives: To identify predictors of interest in predictive testing for FDRs and patients, and to assess the likelihood of patients communicating information about RA risk to their FDRs.

Methods: Surveys were completed by 482 RA patients and 397 of their FDRs. Patients were invited to complete the survey and to provide another to their relatives. Spearman's Rank Correlations were used to assess relationships between interest in predictive testing/ likelihood of risk communication and potential predictor variables.

Results: FDRs had a median age of 41 years, $64 \%$ were female. $57 \%$ were definitely interested and $36 \%$ were probably interested in taking a predictive test for RA. Several predictors were found to be associated with interest (table 1).

Table 1. Spearman's correlations for relatives' and patients' interest in predictive testing. After applying a Bonferonni adjustment, $p$ values were taken as statistically significant at $p \leq 0.003$.

\begin{tabular}{|c|c|c|c|c|}
\hline \multirow[b]{2}{*}{ Predictors of interest in predictive testing } & \multicolumn{2}{|c|}{ FDRs } & \multicolumn{2}{|c|}{ Patients } \\
\hline & rs & $\mathrm{P}$ & rs & $\mathrm{P}$ \\
\hline Brief Illness Perception Questionnaire & 0.11 & 0.03 & 0.09 & 0.05 \\
\hline Consequences & $0.16^{*}$ & $0.002^{*}$ & 0.10 & 0.03 \\
\hline Timeline & 0.09 & 0.07 & -0.05 & 0.28 \\
\hline Personal control & -0.03 & 0.59 & -0.02 & 0.68 \\
\hline Treatment control & -0.02 & 0.76 & 0.02 & 0.74 \\
\hline Identity & 0.09 & 0.09 & 0.12 & 0.01 \\
\hline Concern & $0.21^{*}$ & $<0.001^{\star}$ & $0.16^{\star}$ & $<0.001^{*}$ \\
\hline Coherence & 0.11 & 0.03 & 0.007 & 0.88 \\
\hline Emotional & 0.12 & 0.02 & 0.11 & 0.02 \\
\hline Information Seeking & $0.35^{*}$ & $<0.001^{*}$ & $0.22^{*}$ & $<0.001^{*}$ \\
\hline Decision making & -0.05 & 0.33 & 0.07 & 0.13 \\
\hline Health literacy & 0.03 & 0.52 & 0.02 & 0.62 \\
\hline Health numeracy & -0.06 & 0.23 & -0.02 & 0.72 \\
\hline Brief Avoidance Coping Questionnaire & 0.12 & 0.02 & -0.01 & 0.76 \\
\hline Optimism & 0.06 & 0.26 & -0.07 & 0.12 \\
\hline Health anxiety & $0.16^{\star}$ & $0.001^{*}$ & - & - \\
\hline Perceived risk & $0.37^{*}$ & $<0.001^{*}$ & - & - \\
\hline Rheumatoid Arthritis Impact of Disease & - & - & 0.05 & 0.31 \\
\hline
\end{tabular}

- not applicable

Patients had a median age of 65 years, $71 \%$ were female. $47 \%$ were definitely interested and $30 \%$ were probably interested in their children taking a predictive test. Several predictors were found to be associated with interest (table 1). On a Likert scale from extremely unlikely $(0)$ to extremely likely (4), most patients indicated that they were likely to communicate RA risk information to their children (median score=3).

Conclusion: Interest in predictive testing for RA was high amongst FDRs, and factors including information seeking preference, RA risk perception, concern about RA, perceived consequences of RA and health anxiety were significantly associated with interest. Patients were also willing to communicate information about $\mathrm{RA}$ risk to their children. These findings increase understanding of perceptual variation in those at risk of RA, and will inform the development of information to support decision making in individuals considering predictive tests and preventive interventions. We are currently extending this preliminary analysis by building multivariate models incorporating a range of attitudes about predictive testing, assessing predictors of patients' likelihood of communicating to their FDRs about risk, and the relationship between patients' and FDRs' responses.

References:

[1] Stack RJ et al. BMJ open. 2016; 6(6):e010555.

[2] Falahee $\mathrm{M}$ et al. Arthritis care \& research. 2017; 69(10):1558-65.

Acknowledgments: This work was supported by Versus Arthritis; Grant reference: 21560

Disclosure of Interests: Imogen Wells: None declared, Gwenda Simons: None declared, Rebecca Stack: None declared, Christian Mallen Grant/research support from: My department has received financial grants from BMS for a cardiology trial., Peter Nightingale: None declared, Karim Raza Grant/research support from: KR has received research funding from AbbVie and Pfizer, Consultant of: KR has received honoraria and/or consultancy fees from AbbVie, Sanofi, Lilly, Bristol-Myers Squibb, UCB, Pfizer, Janssen and Roche Chugai, Speakers bureau: KR has received honoraria and/or consultancy fees from AbbVie, Sanofi, Lilly, Bristol-Myers Squibb, UCB, Pfizer, Janssen and Roche Chugai, M. Falahee: None declared

DOI: 10.1136/annrheumdis-2020-eular.2175

\section{OP0265-HPR FACTORS ASSOCIATED WITH MEETING WORK DEMANDS FOR INDIVIDUALS WITH RHEUMATIC DISEASES}

D. Connolly ${ }^{1}$, C. Fitzpatrick ${ }^{1}$, L. O'toole ${ }^{1}$, F. O'shea ${ }^{2}$, M. Doran ${ }^{2} .{ }^{1}$ Trinity College Dublin, Occupational Therapy, Dublin, Ireland; ' $S t$. James' Hospital, Rheumatology, Dublin, Ireland

Background: Almost $65 \%$ of individuals with rheumatic diseases have severe fatigue with the majority of these reporting difficulties in work leading to absenteeism and early retirement. However, there is a lack of research investigating how different types of fatigue impact on work ability.

Objectives: To identify the prevalence of different types of fatigue and explore the association between different types of fatigue and various demands involved in work Methods: A cross-sectional study was carried out with 234 individuals with rheumatic diseases currently in employment. Study measures examined demographics, different types of fatigue (general, physical reduced activity, reduced motivation and mental), ability to meet work demands, disease activity and quality of life.

Results: The majority of participants were female (70\%), had rheumatoid arthritis $(42.7 \%)$, were between $41-50$ years $(30.3 \%)$ and worked full-time $(70 \%)$. One hundred and twenty-eight participants (55\%) had severe fatigue. Physical fatigue was the most prevalent category of fatigue (Table 1). Participants reported managing $50 \%$ of their work demands with physical demands being the most challenging (Table 1). All types of fatigue were significantly associated with the total WRF score (Table 2). Mental fatigue had the strongest association with the total WRF score $(r=0.53, p<0.001)$. On examining the impact of different types of fatigue on meeting work demands, mental fatigue was the most significant predictor of difficulty meeting work demands $(\beta=1.6, \mathrm{SE}=0.37, p<0.001)$

Table 1. MFI and WRF total and category scores

\begin{tabular}{lcccccc}
\hline $\begin{array}{l}\text { WRF } \\
\mathbf{n}=212\end{array}$ & $\begin{array}{c}\text { Total } \\
\text { mean } \\
\text { (SD) }\end{array}$ & $\begin{array}{c}\text { Work Scheduling } \\
\text { Demands mean } \\
\text { (SD) }\end{array}$ & $\begin{array}{c}\text { Output } \\
\text { demands } \\
\text { mean (SD) }\end{array}$ & $\begin{array}{c}\text { Physical } \\
\text { Demands } \\
\text { mean (SD) }\end{array}$ & $\begin{array}{c}\text { Mental } \\
\text { Demands } \\
\text { mean (SD) }\end{array}$ & $\begin{array}{c}\text { Social } \\
\text { Demands } \\
\text { mean (SD) }\end{array}$ \\
\hline $50.3 \%(19.0)$ & $44.6 \%(25.8)$ & $52.9 \%(22.1)$ & $43.3 \%(27.9)$ & $53.4 \%(22.5)$ & $62.4 \%(17.7)$ \\
\hline $\begin{array}{l}\text { MFI } \\
\mathbf{n}=220\end{array}$ & $\begin{array}{c}\text { Total } \\
\text { mean (SD) }\end{array}$ & $\begin{array}{c}\text { Physical fatigue } \\
\text { mean (SD) }\end{array}$ & $\begin{array}{c}\text { Reduced } \\
\text { activity } \\
\text { mean (SD) }\end{array}$ & $\begin{array}{c}\text { Reduced } \\
\text { motivation }\end{array}$ & $\begin{array}{c}\text { Mental fatigue } \\
\text { mean (SD) }\end{array}$ & \\
\hline & $13.4(2.8)$ & $12.5(4.3)$ & $10.1(4.2)$ & $10.2(3.5)$ & $10.3(4.2)$ &
\end{tabular}

Table 2. Correlations for WRF and MFI fatigue categories

\begin{tabular}{lcc}
\hline MFI Category & Correlations with total WRF & p-values \\
\hline General fatigue & .53 & $<0.001$ \\
Mental fatigue & .57 & $<0.001$ \\
Physical fatigue & .48 & $<0.001$ \\
Reduced motivation & .48 & $<0.001$ \\
Reduced activity levels & .41 & $<0.001$
\end{tabular}

Conclusion: Fatigue interferes with many aspects of work performance. However, this study identifies that mental fatigue is the greatest predictor of difficulty in managing work. Self-management interventions focusing on mental fatigue and work ability are required for individuals with rheumatic diseases to manage the demands of their work.

Disclosure of Interests: None declared

DOI: 10.1136/annrheumdis-2020-eular.5550

\section{OP0266-HPR WORK PRODUCTIVITY IN PATIENTS WITH AXIAL AND PERIPHERAL SPONDYLOARTHRITIS}

C. Airoldi ${ }^{1}$, P. Girard Bosch ${ }^{2}$, M. Benegas ${ }^{3}$, V. Duarte ${ }^{4}$, V. Cosentino ${ }^{5}$,

F. Sommerfleck ${ }^{3}$, J. Marin ${ }^{6}$, J. M. Bande ${ }^{7}$, J. Gamba ${ }^{8}$, R. Águila Maldonado ${ }^{9}$, E. Velozo ${ }^{10}$, M. Oliver ${ }^{11}$, R. Nieto ${ }^{1}$, P. Gonzalez ${ }^{12}$, D. Vila ${ }^{13}$, E. Kerzberg ${ }^{5}$,

M. Cosatti ${ }^{14}$, J. Tapia ${ }^{5}$, P. Giorgis ${ }^{15}$, L. L. Macias Oviedo ${ }^{15}$, E. Schneeberger ${ }^{15}$

S. Scarafia ${ }^{16}$, V. Martire ${ }^{2} .{ }^{1}$ Hospital Provincial de Rosario, Rosario,

Argentina; ${ }^{2}$ Instituto Médico Platense, La Plata, Argentina; ${ }^{3}$ Mendez, CABA, Argentina; ${ }^{4}$ Clínica Monte Grande, Buenos Aires, Argentina; ${ }^{5}$ Hospital Ramos Mejia, CABA, Argentina; ${ }^{6}$ Hospital Italiano de Buenos Aires, CABA, Argentina: ${ }^{7}$ Hospital Tornú, CABA, Argentina: ${ }^{8}$ Hospital Posadas, Buenos Aires, Argentina; ${ }^{9}$ Hospital San Martin de La Plata, La Plata, Argentina; ${ }^{10}$ Sanatorio Adventista del Plata, Entre Rios, Argentina; ${ }^{11}$ Hospital Privado de Comunidad de Mar del Plata, Mar del Plata, Argentina; ${ }^{12}$ Clinica DIM, Buenos Aires, Argentina; ${ }^{13}$ Centro Médico Ginecológico de Zárate, Buenos 